\title{
Effect of spraying some plant oils and green tea extracts on growth and nutritional status of Barhee date palms grown under Aswan region conditions
}

\author{
Abdel Aal, A.M.K. ${ }^{1,2}$, F.H. Abdelaziz ${ }^{2}$, F.F. Ahmed ${ }^{2}$, A.Y. Mohamed ${ }^{3}$ and Sahar A. Abdel-Halim ${ }^{3 *}$ \\ ${ }^{1}$ Faculty of Meteorology, Environment and Arid Land Agriculture, King Abdulaziz University, Jeddah, \\ Saudi Arabia \\ ${ }^{2}$ Horticulture Department, Faculty of agriculture, Minia University, Minia, Egypt \\ ${ }^{3}$ Tropical Fruits Department, Horticulture Research Institute, ARC, Egypt
}

\begin{abstract}
The current investigation has been conducted during 2017 and 2018 experimental seasons on 18 years old of Barhee date palms cultivar produced via tissue culture received three sprays of four plant extracts namely moringa, garlic and onion oils as well as the extract of green tea. Each plant extract was used at each at 0.05 to $0.2 \%$. The effect of these plant extracts has been shown on all aspects of all the growth and nutritional status of palms. Plant extracts were sprayed three times, at the first week of March, just after fruit setting (middle of April) and one month later (middle of May). The studied treatments had an announced promotion on all studied growth aspects and palm nutritional status relative to the control treatment (water spray only). Garlic oil was the best treatment in enhancing all studied growth aspects and nutritional status of palms under study. Plant extracts could be arranged ascending in its effects as follows: green tea extract, oils of moringa, onion and garlic, and the promotion were observed among the higher two concentrations of each plant extract. Importantly, stimulation on these characteristics were observed among the higher two concentrations of each plant extracts at 0.1 and $0.2 \%$. In conclusion, for promoting some growth aspects and palm nutritional status of Barhee date palms, it is suggested to spray garlic oil at $0.1 \%$ three times (first week of March, just after fruit setting (middle of April) and one month later (middle of May).
\end{abstract}

Keywords: Palms; Phytogenic; Growth; Palm nutritional status

\section{Introduction}

Using plant extracts especially oils is the alternative for improving the date palms growth and production as well as enhancing fruit quality and marketing. The higher content of plant extracts from nutrients, amino acids, vitamins, antioxidants, plant pigments, phenolic compounds and volatile oils

\footnotetext{
*Corresponding author: Sahar A. Abdel-Halim

Email: wonderful.story34_2019@yahoo.com

Received: February 6, 2021.

Accepted: March 27, 2021.

Published: April 1, 2021.
}

encourage the need for further studies towards their positive effect on fruiting of various fruits crops (Srimal, 1997 and Martos et al., 2007). Previous studies showed that treating Zaghloul date palms (Refaai, 2014), citrus (Cairney, 1995), Anna Apple (Mohamed, et al., 2014), wonderful pomegranates (Ahmed and Gad El- Kareem, 2014), Barhee date palms (Ahmed,2016) and Washington navel oranges (El- Khawaga and Mansour, 2014, Ahmed and Habasy- Randa, 2014 and Abd 
Abdel Aal et al., : SVU-International Journal of Agricultural Sciences, 3 (2): 1-11, 2021

El-Rahman, 2015, Ahmed and HabasyRanda, 2017). The aim of this study is examining the effect of four plant extracts namely green tea extracts as well as oils of moringa, garlic and onion on vegetative growth characteristics and leaf chemical composition of Barhee date palms growing under Aswan climatic conditions.

\section{Materials and Methods}

This study was carried out during the two successive seasons of 2017 and 2018 on 39 palms of Barhee cultivars, 18 years old derived from tissue culture to achieve the goal of this study. The chosen palms were grown in Kom Ombo district Aswan Governorate.
The palms were healthy and in the same growth vigour and were planted at $7.0 \times 7.0$ meters apart in silty clay soil with a water table depth not less than 2 meters. All common horticulture practices were done except those treated with plant extracts and oils under study. Palms were pollinated artificially using hand pollination after two days of female spath cracking and the number of spaths was adjusted to 10 spath /palm. The palms were irrigated by using Nile water through Flood irrigation system. Soil analysis was carried out using the procedures outlined according to Black et al., 1965.

Table (1): Mechanical, physical and chemical analysis of the tested orchard soil

\begin{tabular}{lc}
\hline Constituents & Values \\
\hline Particle size distribution & \\
Sand $\%$ & 9.75 \\
Silt $\%$ & 58.50 \\
Clay $\%$ & 31.75 \\
Texture grade & Silty clay \\
pH $(1: 2.5$ extract) & 7.88 \\
E.C. $\left(1: 2.5\right.$ extract) $\left(\mathrm{mmhos} / 1 \mathrm{~cm} / 25^{\circ} \mathrm{C}\right)$ & 0.93 \\
O.M. $\%$ & 1.98 \\
CaCO $\%$ & 1.11 \\
Macronutrients values & \\
Total N $\%$ & 0.12 \\
P $($ Olsen methods, ppm) & 22.0 \\
K (ammonium acetate, ppm) & 410.0 \\
Mg (ppm) & 81.0 \\
S (ppm) & 5.8 \\
EDTA extractable micronutrients $(\mathrm{ppm})$ & \\
Zn & 2.05 \\
Fe & 10.10 \\
Mn & 9.88 \\
\hline
\end{tabular}

The experiment included the following thirteen treatments:

1- Control (spraying with distil water.

2- Spraying moringa oil at $0.05 \%(0.5 \mathrm{ml} / \mathrm{L})$.

3- Spraying moringa oil at $0.1 \%(1.0 \mathrm{ml} / \mathrm{L})$.

4- Spraying moringa oil at $0.2 \%(2.0 \mathrm{ml} / \mathrm{L})$.

5- Spraying garlic oil at $0.05 \%(0.5 \mathrm{ml} / \mathrm{L})$.

6- Spraying garlic oil at $0.1 \%(1.0 \mathrm{ml} / \mathrm{L})$.

7- Spraying garlic oil at $0.2 \%(2.0 \mathrm{ml} / \mathrm{L})$.
8- Spraying onion oil at $0.05 \%(0.5 \mathrm{ml} / \mathrm{L})$.

9- Spraying onion oil at $0.1 \%(1.0 \mathrm{ml} / \mathrm{L})$.

10- Spraying onion oil at $0.2 \%(2.0 \mathrm{ml} / \mathrm{L})$.

11- Spraying green tea extract at $0.05 \%(0.5$ $\mathrm{g} / \mathrm{L})$.

12- Spraying green tea extract at $0.1 \%(1.0$ g/ L).

13- Spraying green tea extract at $0.2 \%(2.0$ g/ L). Each experiment was replicated 
three times one Barhee palm per each. Spraying was done three times (before hand pollination, just after fruits setting and at one month later). Triton $\mathrm{B}$ as wetting agent was added at 0.05 to all solutions of plant extracts. The analysis of green tea extract as well as oils of moringa, garlic and onion are given in Tables $(2,3,4,5)$.

Table (2): Chemical analysis of green tea extract (according to Lee et al., 2015).

\begin{tabular}{lc} 
Constituent & values \\
\hline Total carbohydrate & $11.0 \mathrm{~g}$ \\
Total fats & $0.4 \mathrm{~g}$ \\
Flavonoids & $0.3 \mathrm{~g}$ \\
Tannins & $2.9 \mathrm{~g}$ \\
Flour & $20.0 \mathrm{mg}$ \\
$\mathrm{N}$ & $1.19 \mathrm{~g}$ \\
$\mathrm{P}$ & $0.24 \mathrm{~g}$ \\
$\mathrm{~K}$ & $1.0 \mathrm{~g}$ \\
Magnesium & $0.5 \mathrm{~g}$ \\
Zinc & $41.0 \mathrm{mg}$ \\
Fe & $51.0 \mathrm{mg}$ \\
Mn & $60.0 \mathrm{mg}$ \\
Coneshin & $0.7 \mathrm{~g}$ \\
Thiamine & $110.0 \mathrm{mg}$ \\
Vitamin A & $90.0 \mathrm{mg}$ \\
Vitamin B & $74.1 \mathrm{mg}$ \\
Vitamin C & $120.0 \mathrm{mg}$ \\
Coffeic acid & $315.0 \mathrm{mg}$ \\
\hline
\end{tabular}

Table (3): Chemical composition of moringa oil (Moringa oleifera). (Mnayer et al., 2014)

Constituent

1- Vitamins (mg/ 100 g F.W.)

Beta-carotene

E

A

$\mathrm{B}_{1}$

$\mathrm{B}_{2}$

$\mathrm{C}$

$\mathrm{K}$

2- Minerals (mg/ 100 g F.W.)

$\mathrm{Ca}$

$\mathrm{K}$

$\mathrm{N}$

$\mathrm{P}$

$\mathrm{Mg}$

3-Amino acids (mg/ 100 g F.W.)

Phenylalanine

Lysine

Leucine

Threonine

Isoleucine

Arginine

Cysteine

Methionine

Tryptophan
Values

1500.0

500.0

900.0

902.0

7.1

180.0

250.0

900.0

500.0

900.0

130.0

199.0

83.9

75.0

89.9

65.0

66.0

66.0

28.0

36.0

33.0 
Table (4): Chemical composition of onion oil (Mnayer et al., 2014)

\begin{tabular}{lc}
\hline Constituent & values \\
\hline 1- Propenyl propyl disulfide a & 7.26 \\
Methyl propyl trisulfide & 5.20 \\
Menthone & 0.34 \\
Dimethyl tetrasulfide & 0.15 \\
Dipropyl trisulfide & 17.10 \\
Eugenol & 3.07 \\
2- Methyl -3, 4-dithiaheptane & 6.48 \\
Dipropyte trasulfide & 0.55 \\
Dipropyl disulfide & 30.92 \\
Allyl propyl sulfide & 0.42 \\
Dimethyl trisulfide & 0.30 \\
\hline
\end{tabular}

Table (5): Chemical composition of garlic oil (according to Mnayer et al., 2014).

\begin{tabular}{lc}
\hline Constituent & Values \\
& (mg/ 100 g D.W.) \\
\hline Dipropyl disulfide & 0.25 \\
Diallyl disulfide & 37.90 \\
Dimethyl trisulfide & 0.33 \\
Dimethyl thiophene & 0.08 \\
Allyl methyl disulfide & 3.69 \\
Methyl propyl disulfide & 0.25 \\
Methyl 1- propenyl disulfide a & 0.46 \\
Allyl propyl sulfide & 0.09 \\
Bis-)1- propenyl) - sulfide a & 0.08 \\
Diallyl sulfide & 6.59 \\
Dimethyl disulfide & 0.15 \\
Allyl methyl teterosulfide & 1.07 \\
Allyl propyl trisulfide & 0.23 \\
Dially trisulfide & 28.06 \\
Eugenal & 0.23 \\
\hline
\end{tabular}

Randomized complete block design (RCBD) was adopted which the experiment included thirteen treatments and each treatment was replicated three times, one palm per each.

During both seasons of study, the following measurements were recorded:

1-Vegetative growth characteristics namely leaflet length and width, number of leaflets /leaf, average width and length of leaf, leaflet area was determined using (Ahmed and Morsy, 1999) and then leaf area, number of spines per leaf as well as spine length were calculated.

Equation: leaflet area (W x L) x $0.67+$ 10.29 in which $\mathrm{W}$ and $\mathrm{L}$ are the maximum width and length of leaflet. Then leaf area 
$(\mathrm{cm})^{2}$ was calculated by multiplying the amount of leaflets / leaf by the area of leaflet. Number of spines per leaf as well as spine length $(\mathrm{cm})$ were also recorded.

2- Leaf pigments of chlorophyll a, b, total chlorophylls and total carotenoids (as $\mathrm{mg} /$ 1 g F.W.) (Von Wettstein, 1957 and Hiscox and Isralstam, 1979).

3- Leaf chemical components of N, P, K and $\mathrm{Mg}$ (as\%) (Summer, 1985; Chapman and Pratt, 1965; Peach and Tracey, 1968; Piper, 1950 and Cottenie et al., 1982).

Statistical analysis was done according to (Snedecor and Cochran, 1980) New L.S.D. test at $5 \%$ values was used for comparing treatment means.

\section{Results and Discussion}

\section{1- Vegetative growth characteristics:}

Data in Tables $6 \& 7$ clearly show that spraying plant extracts namely moringa oil, garlic oil, onion oil and green tea extract at 0.05 to $0.2 \%$ significantly enhanced all growth aspects of Barhee date palms e.g., pinnae length, pinnae width, pinnae area, number of pinnae/ leafs, leaf area, leaf length, leaf width, number of spines/ leaf and spine length relative to the control treatment. The simulation was appreciably related to the increase in the concentrations of each plant extracts. The outstanding effects on the investigated growth characteristics of these plant extracts could be arranged as follows, in ascending order green tea extract, moringa oil, onion oil and garlic oil. Increasing concentrations of each plant extracts from 0.1 to $0.2 \%$ failed to show a significant promotion on these growth aspects. Significant differences on these growth traits were observed between the four plant extracts. The maximum values of pinnae length $(51.2 \&$ $51.5 \mathrm{~cm})$, spine width $(2.53 \mathrm{~m} \& 2.56 \mathrm{~cm})$, pinnae area $\left(52.59 \& 52.66 \mathrm{~cm}^{2}\right)$, number of pinnae / leaf ( $230.0 \& 233.0$ pinnae), leaf area $\left(1.38 \& 1.41 \mathrm{~m}^{2}\right)$ leaf length $(381.2 \& 383.0$ $\mathrm{cm})$, leaf width $(27.3 \& 27.5 \mathrm{~cm})$, number of spines/ leaf (34.5 \& 35.0 spines) and spine length $(14.1 \& 14.5 \mathrm{~cm})$ were recorded on the palms received three sprays of garlic oil at $0.2 \%$. The minimum values were observed on the control treatment. These results were observed during both seasons of study.

Data in Tables 8 \& 9 obviously reveal that chlorophyll a, b and total chlorophylls and total carotenoids as well as $\mathrm{N}, \mathrm{P}, \mathrm{K}$ and $\mathrm{Mg}$ in the leaves of Barhee date palms were significantly varies between the thirteen plant extract treatments.

The previous characteristics were significantly enhanced in response to the treatments compared to the control treatment. Using plant extracts of green tea extract, moringa oil, onion oil and garlic oil significantly maximized these leaf components. Increasing concentrations of each plant extracts from 0.1 to $0.2 \%$ had no significant effect on these leaf components. The maximum values of chlorophyll a $(4.23 \&$ $4.30 \mathrm{mg} / \mathrm{g}$ F.W.), chlorophyll b $(1.70 \& 1.71$ $\mathrm{mg} / \mathrm{g}$ F.W.), total chlorophylls (5.93 \& 6.01 $\mathrm{mg} / \mathrm{g}$ F.W.) total carotenoids $(1.47 \& 1.50$ mg/ g F.W.), N (1.94 \& 1.96\%), P (0.26 \& $0.27 \%), \mathrm{K}(1.55 \& 1.58 \%)$ and $\mathrm{Mg}(0.93 \&$ $0.95 \%$ ) were recorded on the palms received three sprays of garlic oil at $0.2 \%$.

The untreated palms produced the lowest values. These results were true during both seasons of study. The outstanding effect of moringa oil on growth palm nutritional status might be attributed to their higher content of proteins, amino acids nutrients, vitamins and antioxidants (Srimal, 1997 and Martos et al., 2007). The promoting effect of garlic oil and onion oil on growth of Barhee date palm might be ascribed to its content of Sulphur containing compounds and amino acid which includes the presence of the volatile flavour compounds. 
Table (6): Effect of spraying oils of moringa, garlic and onion and green tea extract on some vegetative growth characteristics of Barhee date palms during 2017 and 2018 seasons.

\begin{tabular}{|c|c|c|c|c|c|c|c|c|c|c|}
\hline \multirow[t]{2}{*}{ Treatments } & \multicolumn{2}{|c|}{$\begin{array}{l}\text { Pinnae length } \\
\text { (cm.) }\end{array}$} & \multicolumn{2}{|c|}{$\begin{array}{l}\text { Pinnae width } \\
\text { (cm.) }\end{array}$} & \multicolumn{2}{|c|}{$\begin{array}{l}\text { Pinnae area } \\
\qquad(\mathrm{cm})^{2}\end{array}$} & \multicolumn{2}{|c|}{$\begin{array}{l}\text { Number of } \\
\text { pinnae / leaf }\end{array}$} & \multicolumn{2}{|c|}{$\begin{array}{l}\text { Leaf area } \\
\qquad(\mathrm{m})^{2}\end{array}$} \\
\hline & 2017 & 2018 & 2017 & 2018 & 2017 & 2018 & 2017 & 2018 & 2017 & 2018 \\
\hline 1- Control (spraying with distil water) & 45.6 & 45.8 & 2.20 & 2.22 & 48.00 & 48.11 & 205.0 & 204.0 & 1.00 & 1.02 \\
\hline 2-Spraying moringa oil at $0.05 \%$ & 47.6 & 47.9 & 2.33 & 2.35 & 50.18 & 50.25 & 215.0 & 216.0 & 1.13 & 1.14 \\
\hline 3- Spraying moringa oil at $0.1 \%$ & 48.0 & 48.3 & 2.36 & 2.38 & 50.40 & 50.61 & 219.0 & 220.0 & 1.16 & 1.17 \\
\hline 4-Spraying moringa oil at $0.2 \%$ & 48.6 & 49.0 & 2.38 & 2.40 & 50.51 & 51.70 & 221.0 & 222.0 & 1.17 & 1.18 \\
\hline 5- Spraying garlic oil at $0.05 \%$ & 50.5 & 50.8 & 2.49 & 2.50 & 52.00 & 52.16 & 226.0 & 228.0 & 1.30 & 1.31 \\
\hline 6- Spraying garlic oil at $0.1 \%$ & 50.9 & 51.2 & 2.52 & 2.54 & 52.38 & 52.49 & 229.0 & 231.0 & 1.36 & 1.38 \\
\hline 7- Spraying garlic oil at $0.2 \%$ & 51.2 & 51.5 & 2.53 & 2.56 & 52.59 & 52.66 & 230.0 & 233.0 & 1.38 & 1.41 \\
\hline 8- Spraying onion oil at $0.05 \%$ & 49.0 & 49.3 & 2.39 & 2.41 & 51.00 & 51.36 & 222.0 & 224.0 & 1.20 & 1.22 \\
\hline 9- Spraying onion oil at $0.1 \%$ & 49.5 & 49.8 & 2.42 & 2.45 & 51.60 & 51.76 & 224.0 & 227.0 & 1.25 & 1.27 \\
\hline 10-Spraying onion oil at $0.2 \%$ & 50.0 & 50.2 & 2.44 & 2.47 & 51.75 & 51.89 & 225.0 & 228.0 & 1.27 & 1.29 \\
\hline 11- Spraying green tea extract at $0.05 \%$ & 46.0 & 46.3 & 2.25 & 2.26 & 49.50 & 49.66 & 209.0 & 211.0 & 1.08 & 1.09 \\
\hline 12- Spraying green tea extract at $0.1 \%$ & 46.4 & 46.5 & 2.29 & 2.30 & 49.86 & 50.00 & 211.0 & 214.0 & 1.11 & 1.12 \\
\hline 13- Spraying green tea extract at $0.2 \%$ & 47.0 & 47.3 & 2.31 & 2.32 & 50.05 & 50.15 & 214.0 & 216.0 & 1.12 & 1.13 \\
\hline New L.S.D. at $5 \%$ & 0.9 & 0.8 & 0.04 & 0.03 & 0.9 & 0.9 & 2.0 & 2.0 & 0.04 & 0.05 \\
\hline
\end{tabular}


Abdel Aal et al., : SVU-International Journal of Agricultural Sciences, 3 (2): 1-11, 2021

Table (7): Effect of spraying oils of moringa, garlic and onion and green tea extract on some vegetative growth characteristics of Barhee date palms during 2017 and 2018 seasons.

\begin{tabular}{|c|c|c|c|c|c|c|c|c|}
\hline \multirow[t]{2}{*}{ Treatments } & \multicolumn{2}{|c|}{ Leaf length $(\mathrm{cm})$} & \multicolumn{2}{|c|}{ Leaf width $(\mathrm{cm})$} & \multicolumn{2}{|c|}{$\begin{array}{c}\text { Number of Spines/ } \\
\text { Leaf }\end{array}$} & \multicolumn{2}{|c|}{ Spine Length $(\mathrm{cm})$} \\
\hline & 2017 & 2018 & 2017 & 2018 & 2017 & 2018 & 2017 & 2018 \\
\hline 1- Control (spraying with distil water) & 340.0 & 342.0 & 22.2 & 22.5 & 18.0 & 18.0 & 10.2 & 10.5 \\
\hline 2-Spraying moringa oil at $0.05 \%$ & 356.0 & 360.0 & 23.6 & 23.9 & 23.0 & 24.0 & 11.4 & 11.5 \\
\hline 3- Spraying moringa oil at $0.1 \%$ & 360.4 & 363.0 & 24.1 & 24.4 & 24.5 & 25.0 & 11.8 & 12.0 \\
\hline 4-Spraying moringa oil at $0.2 \%$ & 363.1 & 365.5 & 24.3 & 24.6 & 25.0 & 26.0 & 12.1 & 12.3 \\
\hline 5- Spraying garlic oil at $0.05 \%$ & 374.5 & 375.2 & 26.4 & 26.9 & 30.0 & 31.5 & 13.3 & 13.5 \\
\hline 6- Spraying garlic oil at $0.1 \%$ & 379.3 & 381.0 & 27.0 & 27.3 & 33.5 & 34.5 & 13.7 & 14.2 \\
\hline 7- Spraying garlic oil at $0.2 \%$ & 381.2 & 383.0 & 27.3 & 27.5 & 34.5 & 35.0 & 14.1 & 14.5 \\
\hline 8- Spraying onion oil at $0.05 \%$ & 365.2 & 366.0 & 24.9 & 25.2 & 26.5 & 27.5 & 12.5 & 12.8 \\
\hline 9- Spraying onion oil at $0.1 \%$ & 369.5 & 371.0 & 25.5 & 25.8 & 28.5 & 29.5 & 12.9 & 13.0 \\
\hline 10 -Spraying onion oil at $0.2 \%$ & 371.4 & 373.5 & 25.8 & 26.2 & 29.5 & 30.0 & 13.1 & 13.2 \\
\hline 11- Spraying green tea extract at $0.05 \%$ & 348.2 & 350.0 & 22.6 & 22.8 & 19.5 & 20.0 & 10.6 & 10.7 \\
\hline 12- Spraying green tea extract at $0.1 \%$ & 352.2 & 353.0 & 23.0 & 23.1 & 21.0 & 21.0 & 10.9 & 11.0 \\
\hline 13- Spraying green tea extract at $0.2 \%$ & 353.5 & 356.0 & 23.3 & 23.3 & 22.0 & 22.5 & 11.1 & 11.2 \\
\hline New L.S.D. at $5 \%$ & 2.2 & 2.3 & 0.4 & 0.5 & 1.7 & 2.0 & 0.6 & 0.7 \\
\hline
\end{tabular}


Table (8): Effect of spraying oils of moringa, garlic and onion and green tea extract on some leaf pigments of Barhee date palms during 2017 and 2018 seasons.

\begin{tabular}{|c|c|c|c|c|c|c|c|c|}
\hline \multirow[t]{2}{*}{ Treatments } & \multicolumn{2}{|c|}{$\begin{array}{l}\text { Chlorophyll a } \\
\text { (mg/1.0 g F.W.) }\end{array}$} & \multicolumn{2}{|c|}{$\begin{array}{l}\text { Chlorophyll b } \\
\text { (mg/1.0g F.W.) }\end{array}$} & \multicolumn{2}{|c|}{$\begin{array}{c}\text { Total } \\
\text { Chlorophylls } \\
\text { (mg/1.0 g F.W.) }\end{array}$} & \multicolumn{2}{|c|}{$\begin{array}{l}\text { Total Carotenoids } \\
\text { (mg/1.0 g F.W) }\end{array}$} \\
\hline & 2017 & 2018 & 2017 & 2018 & 2017 & 2018 & 2017 & 2018 \\
\hline 1- Control (spraying with distil water) & 3.18 & 3.21 & 1.20 & 1.21 & 4.38 & 4.42 & 1.02 & 1.02 \\
\hline 2-Spraying moringa oil at $0.05 \%$ & 3.28 & 3.30 & 1.35 & 1.36 & 4.63 & 4.66 & 1.18 & 1.20 \\
\hline 3- Spraying moringa oil at $0.1 \%$ & 3.35 & 3.36 & 1.42 & 1.43 & 4.77 & 4.79 & 1.26 & 1.27 \\
\hline 4-Spraying moringa oil at $0.2 \%$ & 3.38 & 3.39 & 1.44 & 1.45 & 4.82 & 4.84 & 1.28 & 1.30 \\
\hline 5- Spraying garlic oil at $0.05 \%$ & 3.98 & 4.11 & 1.60 & 1.63 & 5.58 & 5.78 & 1.41 & 1.43 \\
\hline 6- Spraying garlic oil at $0.1 \%$ & 4.18 & 4.22 & 1.66 & 1.68 & 5.84 & 5.90 & 1.46 & 1.49 \\
\hline 7- Spraying garlic oil at $0.2 \%$ & 4.23 & 4.30 & 1.70 & 1.71 & 5.93 & 6.01 & 1.47 & 1.50 \\
\hline 8- Spraying onion oil at $0.05 \%$ & 3.40 & 3.44 & 1.45 & 1.47 & 4.85 & 4.91 & 1.30 & 1.31 \\
\hline 9- Spraying onion oil at $0.1 \%$ & 3.61 & 3.66 & 1.52 & 1.54 & 5.13 & 5.20 & 1.35 & 1.37 \\
\hline 10-Spraying onion oil at $0.2 \%$ & 3.70 & 3.72 & 1.55 & 1.58 & 5.25 & 5.30 & 1.36 & 1.38 \\
\hline 11- Spraying green tea extract at $0.05 \%$ & 3.21 & 3.22 & 1.25 & 1.27 & 4.46 & 4.49 & 1.07 & 1.08 \\
\hline 12- Spraying green tea extract at $0.1 \%$ & 3.25 & 3.27 & 1.31 & 1.33 & 4.56 & 4.60 & 1.11 & 1.12 \\
\hline 13 - Spraying green tea extract at $0.2 \%$ & 3.26 & 3.29 & 1.33 & 1.35 & 4.59 & 4.64 & 1.13 & 1.15 \\
\hline New L.S.D. at $5 \%$ & 0.04 & 0.03 & 0.03 & 0.03 & 0.06 & 0.07 & 0.03 & 0.02 \\
\hline
\end{tabular}


Abdel Aal et al., : SVU-International Journal of Agricultural Sciences, 3 (2): 1-11, 2021

Table (9): Effect of spraying oils of moringa, garlic and onion and green tea extract on the percentages of $\mathrm{N}, \mathrm{P}, \mathrm{K}$ and $\mathrm{Mg}$ in the leaves of Barhee date palms during 2017 and 2018 seasons.

\begin{tabular}{|c|c|c|c|c|c|c|c|c|}
\hline \multirow{2}{*}{ Treatments } & \multicolumn{2}{|c|}{ Leaf N\% } & \multicolumn{2}{|c|}{ Leaf P\% } & \multicolumn{2}{|c|}{ Leaf $\mathrm{K} \%$} & \multicolumn{2}{|c|}{ Leaf $\mathrm{Mg} \%$} \\
\hline & 2017 & 2018 & 2017 & 2018 & 2017 & 2018 & 2017 & 2018 \\
\hline 1- Control (spraying with distil water) & 1.44 & 1.45 & 0.11 & 0.12 & 1.10 & 1.11 & 0.48 & 0.53 \\
\hline 2-Spraying moringa oil at $0.05 \%$ & 1.60 & 1.66 & 0.16 & 0.17 & 1.25 & 1.27 & 0.61 & 0.62 \\
\hline 3- Spraying moringa oil at $0.1 \%$ & 1.71 & 1.78 & 0.19 & 0.19 & 1.32 & 1.33 & 0.70 & 0.73 \\
\hline 4-Spraying moringa oil at $0.2 \%$ & 1.73 & 1.80 & 0.20 & 0.20 & 1.34 & 1.35 & 0.73 & 0.75 \\
\hline 5- Spraying garlic oil at $0.05 \%$ & 1.88 & 1.90 & 0.24 & 0.25 & 1.45 & 1.47 & 0.85 & 0.86 \\
\hline 6- Spraying garlic oil at $0.1 \%$ & 1.92 & 1.94 & 0.25 & 0.26 & 1.53 & 1.55 & 0.91 & 0.93 \\
\hline 7- Spraying garlic oil at $0.2 \%$ & 1.94 & 1.96 & 0.26 & 0.27 & 1.55 & 1.58 & 0.93 & 0.95 \\
\hline 8- Spraying onion oil at $0.05 \%$ & 1.75 & 1.77 & 0.21 & 0.22 & 1.35 & 1.37 & 0.75 & 0.77 \\
\hline 9- Spraying onion oil at $0.1 \%$ & 1.81 & 1.83 & 0.23 & 0.24 & 1.40 & 1.43 & 0.83 & 0.84 \\
\hline 10 -Spraying onion oil at $0.2 \%$ & 1.83 & 1.85 & 0.24 & 0.25 & 1.42 & 1.44 & 0.84 & 0.85 \\
\hline 11- Spraying green tea extract at $0.05 \%$ & 1.52 & 1.53 & 0.12 & 0.13 & 1.15 & 1.16 & 0.51 & 0.54 \\
\hline 12- Spraying green tea extract at $0.1 \%$ & 1.57 & 1.58 & 0.14 & 0.15 & 1.21 & 1.22 & 0.56 & 0.59 \\
\hline 13- Spraying green tea extract at $0.2 \%$ & 1.58 & 1.59 & 0.15 & 0.16 & 1.23 & 1.24 & 0.58 & 0.60 \\
\hline New L.S.D. at $5 \%$ & 0.07 & 0.08 & 0.03 & 0.05 & 0.04 & 0.06 & 0.06 & 0.08 \\
\hline
\end{tabular}




\section{References}

Abada, M.A.M. (2014) "A comparative study for the effect of green tea extract and some antioxidants on Thompson seedless grapevines" Inter. J. of Plant \& Soil Sci. 3 (10): 1333-1342.

Abd El- Rahman, M.M.A. (2015) "Yield and fruit quality of Washington navel oranges as influenced by foliar application of fenugreek and rocket seed sprouts" World Rural Observations. 7 (2): 99-104.

Abdel- Latif, M.M. (2018) "Effect of spraying salicylic acid and some plant extracts on fruiting of Superior grapevines" $P h$. Thesis Fac. of Agric. Minia Univ. Egypt.

Ahmed, E.F.S. (2016) "Impact of spraying Moringa oil and turmeric extract on fruiting of Barhee date palms" J. Biol. Chem. Environ. Sci. 11(3): 359- 365.

Ahmed, F.F. and Gad El- Kareem, R.M. (2014) "Effect of spraying wheat seed sprout and some nutrients on fruiting of wonderful pomegranate trees" World Rural Observation. 6(4): 115-120.

Ahmed, F.F. and Habasy- Randa, E.Y. (2017) "Response of Balady mandarin trees to spraying some plant extracts" J. Biol. Chem. Environ. Sci. 12 (1): 523-544.

Ahmed, F.F. and Habasy- Randa, E.Y. (2014) "Productive performance of Washington Navel orange trees in relation to foliar application of barley seed sprout and royal Jelly" World Rural Observations. 6 (4): 109-114.

Ahmed, F.F. and Morsy, M.H. (1999) "A new method for measuring leaf area in different fruit species" Minia J. of Agric. Res. 8 Develop., Vol. (19): 97-105.

Ahmed, F.F.; Mansour, A.E.M.; Montasser, M.A.A.; Merwad, M.A. and Mostafa, E.A.M. (2013) "Response of Valencia orange trees to foliar application of Roselle, turmeric and seaweed extracts" $J$. of Applied Science Research. 9 (1): 960969.
Al- Wasfy, M.M.; Ahmed, F.F. and ElMasry, A.M. (2013) "Behaviour of Washington Navel orange trees to foliar application of some plant extract. Hort" Science Journal of Suez Canal Univ. Vol. 1: 281-285.

Black, C.V.; Evans, D..; Ersminger, L.E. White, J.L. and Clark, F.E. (1965) "Methods of Soil Analysis" Amer. Soc. Agron Inc. Bull. Medison, Wisconsin, U.S.A. pp. 891-1400.

Cairney, E. (1995) "Sprouts (Handbook Argyll publishing Glen drangel Sargyl PA 223 AE Scotland pp. 20-25.

Chapman, H.D. and Pratt, P.P. (1965) "Method of Analysis for soils, Plants and water" Univ. of California Division of Agric., Sci., 172-173.

Cottenie, A.; Cerloo, A.; Verloo, M.; Velghe, M. and Camerlynck, R. (1982) "Chemical analysis of Plant and Soil. Ghent. Belgium. Laboratory of Analytical and agrochemistry" State Univ. pp. 200- 210.

El- Khawaga, A.S. and Mansour, A.G.M. (2014) "Promoting productivity of Washington Navel orange trees by using some crop seed sprout extracts. Silicon and glutathione" Middle east Journal of Applied Sciences. 4 (3): 779-785.

El-Salhy, A.M.; Ibrahim, R.H.; Megawer, M.A. and Abd El-Hafiz, G.N. (2017) "Effect of plant extracts spraying on growth and fruiting of Flame seedless grapevines" Assuit J. Agric. Sci., 48(3): 188-197.

Grohar, H.N. (1992) "Green tea composition consumption and polyphenmol chemistry Prev" Med. 21: 334-350.

Hegazy, M.U.M. (2015) "Studies on some treatments to improve the productivity of olive fruits and fruit quality" M. Sc. Thesis Fac. of Agric. Suez Canal Univ.

Hiscox, A. and Isralstam, B. (1979) "A method for the extraction of chlorophyll from leaf tissue without maceration can" J. Bot. 57: 1332-1334. 
Koch, H.P. and Lawson, L.D. (1996) "Garlic the science and therapeutic application of Allhim sativnm L. and related species" $2^{\text {nd }}$ Ed. Baltimore MD Williams and Wilkins.

Lee, L.S.; Kim, S.H.; Kim, Y.B. and Kim, Y.C. (2015) "Quantitative analysis of major constituents in green tea with different plucking periods and their antioxidant activity" Molecules, 19(7), 9173-9186.

Martos, M.V.; Tolanda, R.N.; Juana, F.L. and Jose, A.P. (2007) "Chemical composition of the essential of oils. Obtained from some spices widely used in Mediterranean region Acta" Chin. Slov. 54: 921-956.

Mnayer, D.; Fabiano- Tixier, A.S. Petitcolas, E. Hamioeh, T.; Nehme, N. Ferrant, C.; Fernanez, X. and Chemat, F. (2014) "Chemical composition, antibacterial and antioxidant activities of six essentials oils from the Allia Ceae family" Moelcules 19(12): 20034-20053.

Mohamed, A.; El- Yazal, S. and Rady, M. (2014) "Exogenous onion extract has tens bud break, positively alters enzyme activity, hormone, amino acids and phenol contents, and improves fruit quality in "Anna" apple trees" Scientia Horticultuare 169- 154-160.

Mohamed, Y.A. and Mohamed, H.H. (2013) "The synergistic effects of using turmeric with various nutrients on fruiting of Sewy date palms" Hort. Science Journal of Suez Canal Univ. 2013; Vol. 1: 287-291.

Peach, K. and Tracy, M. V. (1968) "Modem methods of plants analysis" Vol. II, p. 36 38. Inter Sci. New York.

Piper, C.S. (1950) "Soil and Plant Analysis, Inter Science New- York pp. 48-1 10.

Refaai, M.M. (2014) "Response of Zaghloul date palms grown under Minia region conditions to spraying wheat seed sprout extract and nano- boron Stem" Cell 5 (4): 22-28.
Snedecor, G.A.V. and Cochran, G. W. (1980) "Statistical methods" $7^{\text {th }}$ ED. Iowa State Univ. Press. Ames, Iowa, U. S. A 507.

Srimal, R.C. (1997) "Turmeric a brief review of medical properties" Filoterapoa, 68)6): 483-494.

Summer, M.E. (1985) "Diagnosis and Recommendation Integrated System (DRIS) as a guide to orchard fertilization" Hort. Abst. 55 (88): 7502.

Uwakiem, M.Kh. (2014) "The synergistic effect of spraying some plant extracts with some macro and micronutrients of Thompson seedless grapevines" International Journal of Plant \& Soil Science 3(10): 1290- 1301.

Von-Wettstein, D. V. (1957) "ChlorophyllLethalc under submikroshopishe formilkechrel der plastiden cell, prp" Trop. Res, Amer. Soc. Hort. Sci. 20 pp. 427-433. 